\title{
Comparative Performance Analysis of Grid-Connected PV Power Systems with Different PV Technologies in the Hot Summer and Cold Winter Zone
}

\author{
Chong Li (1D ${ }^{1,2}$ \\ ${ }^{1}$ School of Electronic Engineering, Nanjing Xiaozhuang University, Nanjing 211171, China \\ ${ }^{2}$ College of Economics and Management, Nanjing University of Aeronautics and Astronautics, Nanjing 211106, China \\ Correspondence should be addressed to Chong Li; chongli630@163.com
}

Received 3 April 2018; Accepted 10 September 2018; Published 14 October 2018

Academic Editor: Giulia Grancini

Copyright (c) 2018 Chong Li. This is an open access article distributed under the Creative Commons Attribution License, which permits unrestricted use, distribution, and reproduction in any medium, provided the original work is properly cited.

\begin{abstract}
The objective of this paper is to establish the performance of $8 \mathrm{~kW}_{\mathrm{p}}$ grid-connected photovoltaic (PV) power systems based on different PV module technologies in Nanjing, China. Nanjing has a hot summer and a cold winter which are considered based on monthly average solar irradiation and ambient temperature specifically for the deployment of grid-connected PV systems. The study focuses on performance assessment of grid-connected PV systems using typical PV modules made of monocrystalline silicon $(\mathrm{m}-\mathrm{Si}$ ), polycrystalline silicon ( $\mathrm{p}$-Si), edge-defined film-fed growth silicon (EFG-Si), cadmium telluride (CdTe) thin film, copper indium selenide (CIS) thin film, heterojunction with intrinsic thin layer (HIT), and hydrogenated amorphous silicon single-junction (a-Si:H single-PV) installed on location. The yearly average energy output, PV module and system efficiency, array yield, final yield, reference yield, performance ratio, monthly average array capture losses, and system losses of seven PV module technologies are all analyzed. The results show that grid-connected PV power system performance depends on geographical location, PV module types, and climate conditions such as solar radiation and ambient temperature. In addition, based on energy output and efficiency, the HIT PV power technology can be considered as the best option and CdTe and p-Si as the least suitable options for this area. The monthly average performance ratio of the CdTe technology was higher than those of other technologies over the monitoring period in Nanjing.
\end{abstract}

\section{Introduction}

Thermal power generation has a number of shortcomings, including consumption of coal, oil, and natural gas resources, serious environmental pollution, and low utilization rate. Solar energy is universal, nonpolluting, vast, noiseless, safe, and inexhaustible. So far, solar energy has experienced vigorous growth around the world and is one of the most prominent renewable energy sources. Therefore, more attention has been paid recently to solar PV power generation to reduce greenhouse gas emissions. The global cumulative installed capacity of solar PV power systems has increased rapidly over the past decade [1-3].

Nanjing $\left(32^{\circ} 02^{\prime} 38^{\prime \prime} \mathrm{N}, 118^{\circ} 46^{\prime} 43^{\prime \prime} \mathrm{E}\right.$, approximately $67.9 \mathrm{~m}$ above sea level) is the capital of Jiangsu province of China and is located in the southwestern part of Jiangsu province, close to Anhui province, as shown in Figure 1 $[4,5]$. The city covers a total land area of 6597 square kilometers with an estimated population of 8.23 million. Nanjing has a hot summer and a cold winter with a north subtropical monsoon climate with distinct seasons, plentiful sunshine, and rain. The four seasons are distinct in this region, with hot summers and cold winters. The average annual temperature is about $17.8^{\circ} \mathrm{C}$, and precipitation is about 1106 millimeters per year. The annual sunshine is about 2200-3000 hours in Nanjing, and the city has good light conditions, making this region suitable to build a certain capacity of PV power stations. The chemical industry is the main component of heavy industry in Nanjing, creating high energy demand and environmental pressures. In the long term, Nanjing should develop renewable energy sources such as solar energy [6-8]. 


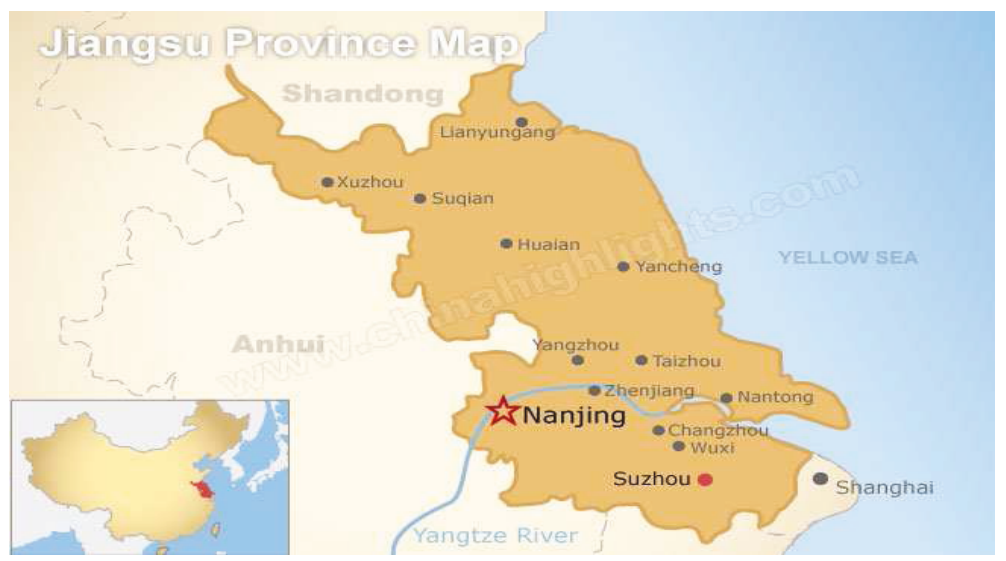

FIGURE 1: Geographical location of Nanjing, China [5].

In recent years, many researchers have studied the performance of grid-connected solar PV power systems in different locations. Kymakis et al. [9] analyzed the performance of a grid-connected PV park on the island of Crete. The performance parameters that were calculated included reference yield, array yield, final array yield, capture losses, system losses, and performance ratio. Ayompe et al. [10] analyzed the performance of a $1.72 \mathrm{~kW}_{\mathrm{p}}$ grid-connected PV system installed in Dublin, Ireland, and its performance parameters were evaluated on a monthly, seasonal, and annual basis. Wittkopf et al. [11] assessed the performance of a $142.5 \mathrm{~kW}_{\mathrm{p}}$ grid-connected BIPV system on the roof of a zero-energy building in Singapore. They found that the performance ratio was lowest for clear days, with high irradiance fluctuations due to higher capture rates and system losses. Al-Sabounchi et al. [12] evaluated the performance of a distributed PV generation system rated at $36 \mathrm{~kW}$ and installed at ground level in the Abu Dhabi industrial area. Results showed that the amount of accumulated dust deposition affected the system seriously. Padmavathi and Daniel [13] examined the performance of a $3 \mathrm{MW}$ grid-connected solar PV plant located in Karnataka State, India. Energy yields, system losses, and component efficiencies were discussed in detail. Farhoodnea et al. [14] presented the performance of an in-campus $3 \mathrm{~kW}_{\mathrm{p}}$ grid-connected polycrystalline silicon PV system using experimental data. Six-month performance data for the system installed at the Universiti Kebangsaan Malaysia campus were used. Sundaram and Babu [15] analyzed the performance of a $5 \mathrm{MW}_{\mathrm{p}}$ grid-connected PV system using the RETscreen software in Sivagangai, India. The annual average daily array yield, reference yield, final yield, module efficiency, inverter efficiency, system efficiency, capture loss, and system loss were discussed. Okello et al. [16] analyzed the performance of a $3.2 \mathrm{~kW}_{\mathrm{p}}$ grid-connected PV system at the Nelson Mandela Metropolitan University, South Africa. System performance was simulated using PVsyst software with measured and Meteonorm-derived climate data sets. Mpholo et al. [17] evaluated the performance of a newly installed $281 \mathrm{~kW}_{\mathrm{p}}$ first grid-connected solar PV farm in Lesotho. The results showed that the area was suitable for grid-connected PV systems. Sidi et al. [18] analyzed the performance of the first large-scale solar PV plant in
Mauritania. Some performance indices such as reference yield, array yield, system yield, performance ratio, capacity factor, and array capture losses were calculated. The results showed that the PV plant performance depended on both insolation and environmental conditions. Dabou et al. [19] presented the effect of weather conditions on the performance of a $1.75 \mathrm{~kW}_{\mathrm{p}}$ grid-connected PV system installed in southern Algeria. The final yield, reference yield, performance ratio, and system efficiency were discussed. Allouhi et al. [20] assessed the performance of two $2 \mathrm{~kW}_{\mathrm{p}}$ gridconnected PV systems in Meknes. Monthly and annual performance indicators such as total energy generated, final yield, capacity factor, and overall system efficiency were evaluated and compared for mono-Si and poly-Si PV technologies using the PVsyst software. Maammeur et al. [21] investigated the performance of a grid-connected PV system for family farms in northwestern Algeria. They found that $49 \%$ of total on-farm electricity consumption came from renewable energy. Lima et al. [22] carried out a performance analysis of a $2.2 \mathrm{~kW}_{\mathrm{p}}$ PV system installed at the State University of Ceará, Fortaleza, Brazil. The results showed that the PV systems performed well.

Up to now, few researchers have focused on the comparative performance of grid-connected solar PV power systems with different PV modules under hot summer and cold winter conditions. There are two main research methodologies available to study the performance of grid-connected PV systems: numerical simulation and experimental investigation methods. The advantages of the numerical simulation method are that it is convenient, quick, low cost, etc. [14, 23-25]. Therefore, this study compares the performance of seven PV technologies under this climate condition using the PVsyst V5.74 tool [26]. Simulations were carried out on the performance of different PV modules, taking into account the solar radiation and ambient temperature of Nanjing.

\section{Description of the Grid-Connected Solar PV Power System}

Figure 2 shows the proposed grid-connected solar PV system. Its main components are PV arrays, DC/DC converters, 


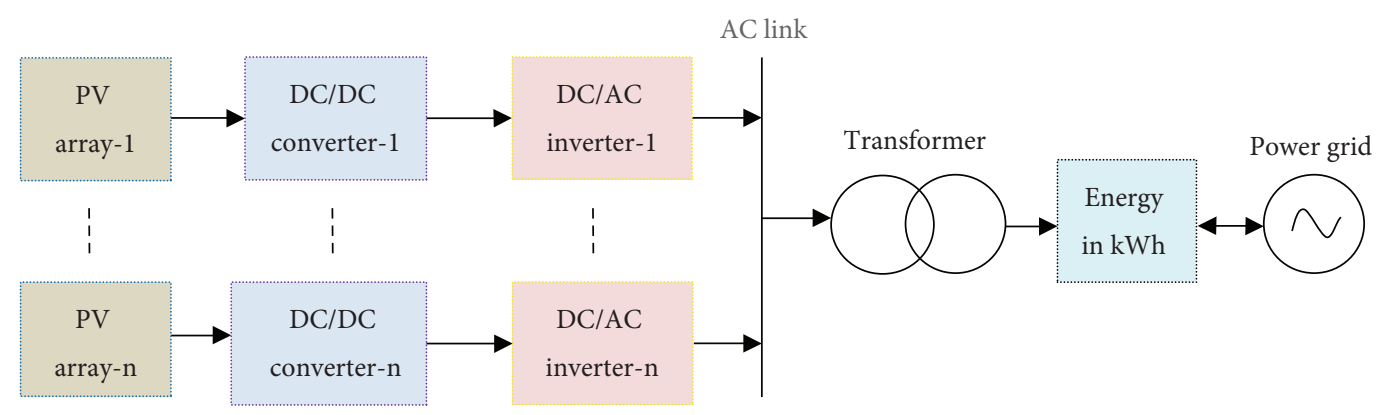

Figure 2: Grid-connected PV power system.

$\mathrm{DC} / \mathrm{AC}$ inverters, a transformer, $\mathrm{DC}$ and $\mathrm{AC}$ cables, and other accessory devices. In this study, the grid-connected PV system was used without batteries. The PV system consisted of 806 modules covering a total area of $77 \mathrm{~m}^{2}$ with an installed capacity of $8 \mathrm{~kW}_{\mathrm{p}}$. HB-1210 $10 \mathrm{~W}_{\mathrm{p}}$ modules were used. The modules were tilted at a fixed angle of $23^{\circ}$ facing south. The Sunway TG $10-600 \mathrm{~V}$ inverter was used to transform the voltage from $\mathrm{DC}$ to $\mathrm{AC}$ and was connected to the utility grid. The inverter had a rated maximum efficiency of $95.3 \%$ and maximum AC power of $8.7 \mathrm{~kW}$ [27-29].

2.1. PV Modules. The $\mathrm{m}-\mathrm{Si}$, $\mathrm{p}-\mathrm{Si}, \mathrm{EFG}-\mathrm{Si}$, CdTe thin-film, CIS thin-film, HIT, and a-Si:H single-PV modules were chosen from the PVsyst product database. Table 1 shows the main specifications of the $\mathrm{PV}$ module types at standard testing conditions (STC): $1 \mathrm{~kW} / \mathrm{m}^{2}$ solar irradiance, $25^{\circ} \mathrm{C}$ cell temperature, and 1.5 air mass (AM) [18].

\section{Methodology}

3.1. Meteorological Data for Nanjing. Local meteorological data, such as solar irradiation and ambient temperature, are important factors for estimating solar PV power system performance. Monthly meteorological data for Nanjing were available with the help of the METEONORM V7.0 software, which was used to generate hourly synthetic meteorological data [30].

Figure 3 shows monthly average solar irradiation parameters for horizontal global irradiation, horizontal diffuse irradiation, global incident irradiation in the collector plane (tilt angle $=23^{\circ}$, azimuth angle $=0^{\circ}$, albedo $=20 \%$ ), and ambient temperature for Nanjing. Monthly average horizontal global irradiation varied from $61 \mathrm{kWh} / \mathrm{m}^{2}$ in January and December to $145 \mathrm{kWh} / \mathrm{m}^{2}$ in July. Monthly average horizontal diffuse irradiation varied from $37 \mathrm{kWh} / \mathrm{m}^{2}$ in January to $95 \mathrm{kWh} /$ $\mathrm{m}^{2}$ in May and July. Monthly average direct normal radiation varied from $35 \mathrm{kWh} / \mathrm{m}^{2}$ in May to $72 \mathrm{kWh} / \mathrm{m}^{2}$ in July. Monthly average ambient temperature varied from $3^{\circ} \mathrm{C}$ in January to $28.7^{\circ} \mathrm{C}$ in July, and the average ambient temperature over the whole year was $16.4^{\circ} \mathrm{C}$.

\subsection{Performance Parameters}

3.2.1. Energy Generated by the Solar PV System. The total daily, monthly, and yearly alternating current (AC) energy generated by the solar PV system over a given period can be obtained as $[22,31]$

$$
\begin{aligned}
& E_{(\mathrm{AC}, d)}=\sum_{h=1}^{24} E_{(\mathrm{AC}, h)}, \\
& E_{(\mathrm{AC}, m)}=\sum_{d=1}^{n} E_{(\mathrm{AC}, d)}, \\
& E_{(\mathrm{AC}, y)}=\sum_{m=1}^{12} E_{(\mathrm{AC}, m)},
\end{aligned}
$$

where $E_{(\mathrm{AC}, h)}$ is the hourly $\mathrm{AC}$ energy output at time $h$ $(\mathrm{kWh}), E_{(\mathrm{AC}, d)}$ is the daily AC energy output $(\mathrm{kWh})$, $E_{(\mathrm{AC}, m)}$ is the monthly AC energy output $(\mathrm{kWh}), E_{(\mathrm{AC}, y)}$ is the yearly AC energy output (kWh), and $n$ is the number of days in one month.

3.2.2. Array Yield $\left(Y_{A}\right)$. The array yield is the ratio of daily, monthly, or yearly direct current (DC) energy output from a PV array to the rated PV array power and is given by [10]

$$
Y_{\mathrm{A}}=\frac{E_{\mathrm{DC}}}{P_{\mathrm{PV}, \text { rated }}},
$$

where $E_{\mathrm{DC}}$ is the total DC energy output from the PV arrays $(\mathrm{kWh})$ and $P_{\mathrm{PV} \text {,rated }}$ is the rated output power of the PV system $\left(\mathrm{kW}_{\mathrm{p}}\right)$.

3.2.3. Final Yield $\left(Y_{F}\right)$. The final yield can be defined as the total AC energy during a given period divided by the rated $\mathrm{PV}$ array power and is given by [18]

$$
Y_{\mathrm{F}}=\frac{E_{\mathrm{AC}}}{P_{\mathrm{PV}, \text { rated }}},
$$

where $E_{\mathrm{AC}}$ is the total $\mathrm{AC}$ energy output from the inverter generated by the PV power system for a specific period (kWh).

3.2.4. Reference Yield $\left(Y_{R}\right)$. The reference yield is the ratio of total in-plane solar radiation to the reference irradiance at standard test conditions (STC). It represents the total in- 


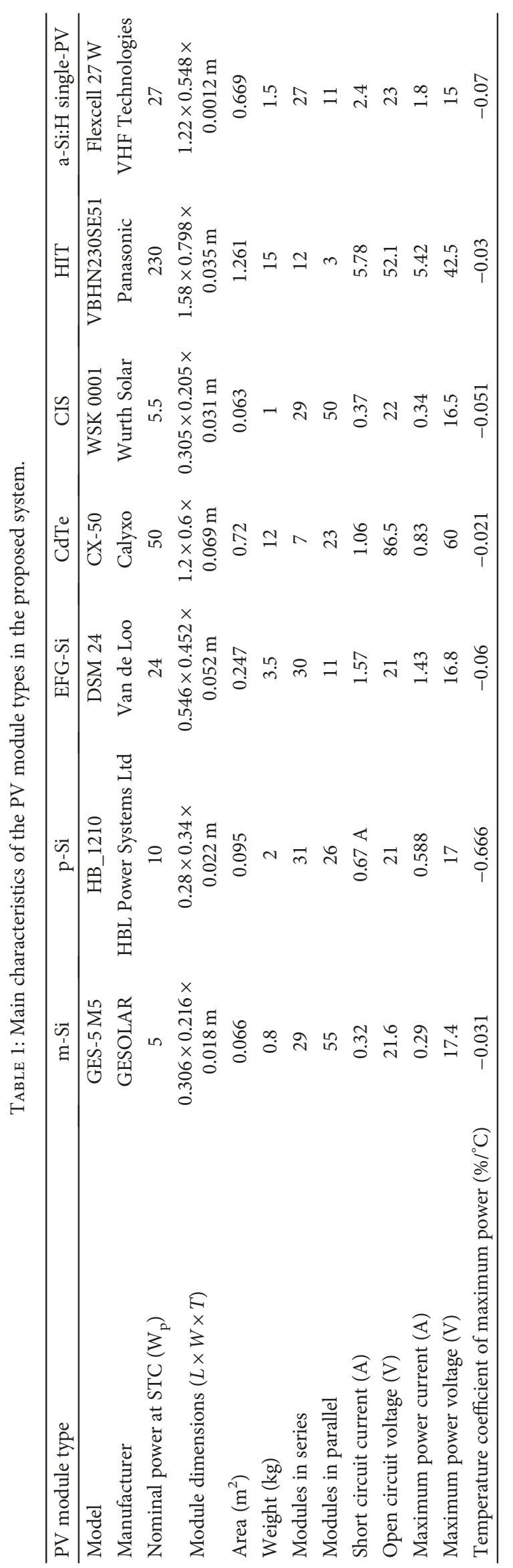




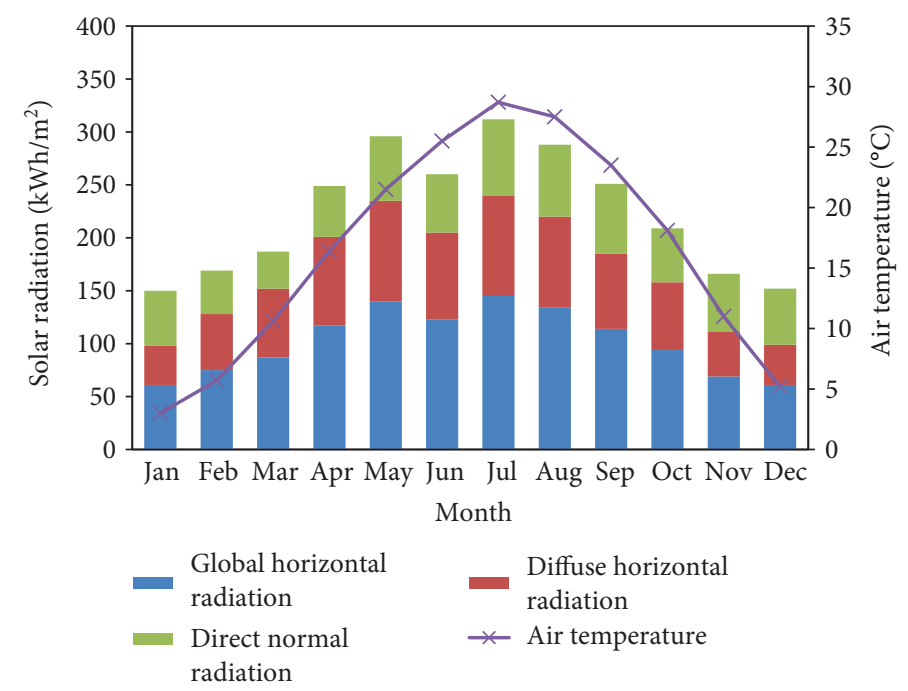

FigURE 3: Mean monthly solar radiation and ambient temperature for Nanjing.

plane solar radiation or an equivalent number of hours at the reference irradiance and is given by $[10,18]$

$$
Y_{\mathrm{R}}=\frac{S_{\mathrm{R}}}{H_{\mathrm{R}}},
$$

where $S_{\mathrm{R}}$ is the total in-plane solar radiation $\left(\mathrm{kWh} / \mathrm{m}^{2}\right)$ and $H_{\mathrm{R}}$ is the array reference irradiance at STC $\left(1 \mathrm{~kW} / \mathrm{m}^{2}\right)$.

3.2.5. Performance Ratio (PR). The performance ratio $(P R)$ is the ratio of the final energy yield of the PV system to the reference yield. It provides information about the overall losses incurred in converting DC to AC power. Therefore, it represents the percentage of energy actually available after deducting energy losses [29, 32, 33]:

$$
\mathrm{PR}=\frac{Y_{\mathrm{F}}}{Y_{\mathrm{R}}} .
$$

3.2.6. $P V$ Module Efficiency $\left(\eta_{P V}\right)$. The PV module efficiency is calculated as [10]

$$
\eta_{\mathrm{PV}}=\frac{E_{\mathrm{DC}}}{S_{\mathrm{R}} A_{\mathrm{PV}}} \times 100 \%,
$$

where $A_{\mathrm{PV}}$ is the PV module total area $\left(\mathrm{m}^{2}\right)$.

3.2.7. PV System Efficiency $\left(\eta_{S}\right)$. The overall PV system conversion efficiency is defined as the energy output from a PV array divided by the total in-plane solar insolation and is given as [10]

$$
\eta_{\mathrm{S}}=\frac{E_{\mathrm{AC}}}{S_{\mathrm{R}} A_{\mathrm{PV}}} \times 100 \%
$$

3.2.8. Array Capture Loss. Array capture loss $\left(L_{\mathrm{A}}\right)$ is due to $\mathrm{PV}$ array losses and is given as $[10,18]$

$$
L_{\mathrm{A}}=Y_{\mathrm{R}}-Y_{\mathrm{A}} \text {. }
$$

3.2.9. System Loss. System loss $\left(L_{\mathrm{s}}\right)$ is due to inverter inefficiencies and is calculated as $[10,18]$

$$
L_{\mathrm{S}}=Y_{\mathrm{A}}-Y_{\mathrm{F}}
$$

\section{Results and Discussion}

In this section, the results of yearly average energy output, PV module and system efficiency, array yield, final yield, reference yield, performance ratio, monthly average array capture losses, and system losses for seven different PV module technologies are discussed.

Figure 4 shows the effective energy output as well as PV array and system efficiency. The yearly average energy outputs of the systems were $8831.1 \mathrm{kWh}, 9556 \mathrm{kWh}$, $8584.4 \mathrm{kWh}, 9570 \mathrm{kWh}, 9411.2 \mathrm{kWh}, 9606 \mathrm{kWh}, \quad$ and 8424.1 kWh for m-Si, p-Si, EFG-Si, CdTe, CIS, HIT, and a-Si:H systems, respectively. The energy output from the p-Si PV system was similar to those from the CdTe and HIT PV systems. The maximum PV module and system efficiencies were $15.7 \%$ and $14.73 \%$, respectively, for the HIT PV module, whereas the minimum efficiencies were $3.15 \%$ and $2.95 \%$, respectively, for the a-Si:H single-PV module system. Therefore, based on energy output and efficiency, HIT PV systems can be considered as the best option and CdTe and $\mathrm{p}$-Si the least suitable options for this location [34].

Figure 5 shows that the monthly array yields for different PV module technologies were different for different months. The array yields of these power systems varied from a minimum value of $2.17 \mathrm{~h} / \mathrm{d}$ in January for an a-Si:H single-PV module system to a maximum value of $4.18 \mathrm{~h} / \mathrm{d}$ in August for a $\mathrm{p}$-Si PV module system.

Figure 6 shows the monthly average final yield of the PV module technologies tested. The AC energy fed to the grid is indicated by the final yield [29]. The a-Si:H single-PV technology had the lowest monthly average final yield in January, with a value of $2.03 \mathrm{~h} / \mathrm{d}$, and a high value of $3.38 \mathrm{~h} / \mathrm{d}$ in 


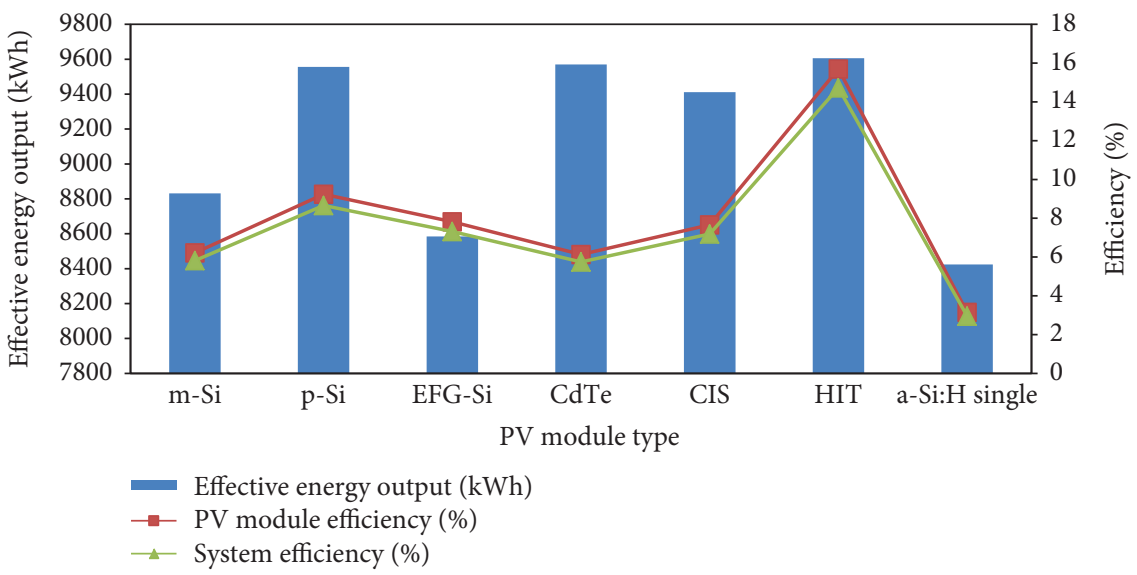

FIGURE 4: Yearly average energy output, PV array, and system efficiency of seven PV module technologies.

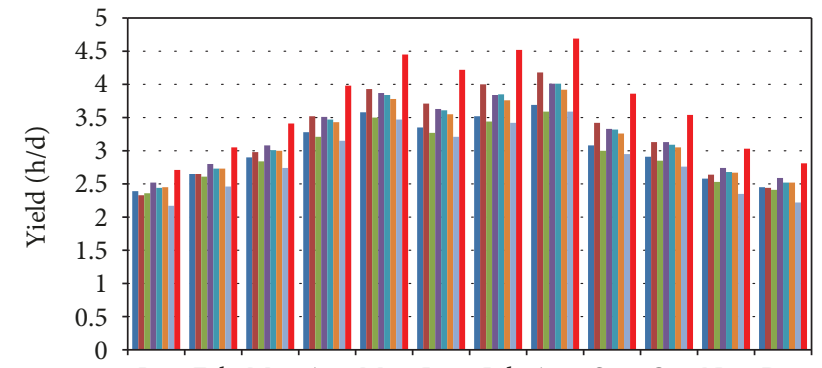

Jan Feb Mar Apr May Jun Jul Aug Sep Oct Nov Dec

$$
\begin{array}{ll} 
& \text { Month } \\
\text { - } \mathrm{m}-\mathrm{Si} & \text { " CIS } \\
\text { - } \mathrm{p}-\mathrm{Si} & =\mathrm{HIT} \\
\text { - EFG-Si } & =\mathrm{a}-\mathrm{Si}: \text { H single } \\
\text { - } \mathrm{CdTe} & \text { - Reference yield }
\end{array}
$$

FIGURE 5: Monthly average array yield of seven PV module technologies compared with the reference yield.

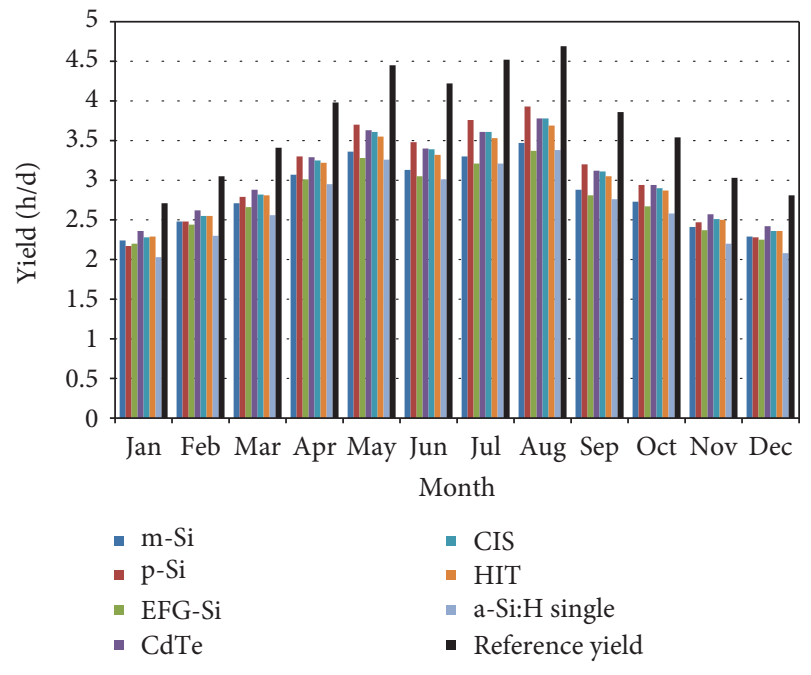

Figure 6: Monthly average final yield of seven PV module technologies compared with the reference yield.

August. The p-Si PV technology has the highest monthly average final yield in August, with a value of $3.93 \mathrm{~h} / \mathrm{d}$, and a low value of $2.17 \mathrm{~h} / \mathrm{d}$ in January.

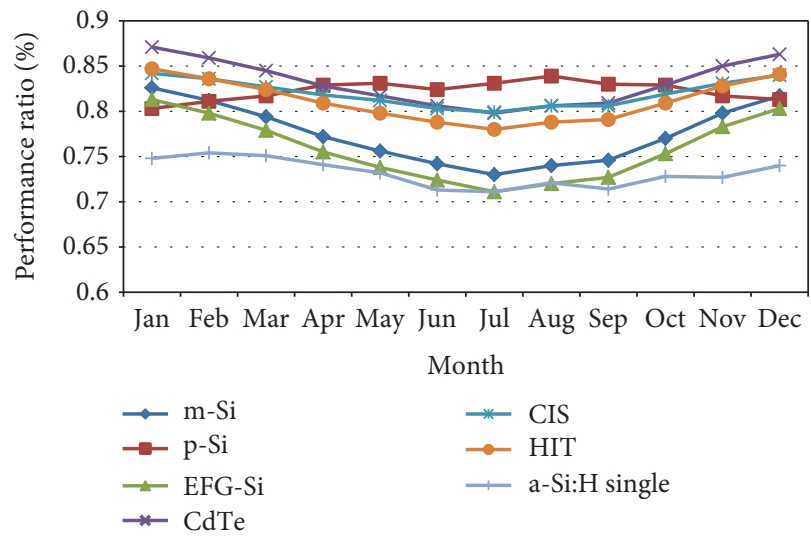

Figure 7: Monthly average performance ratio of seven PV module technologies.

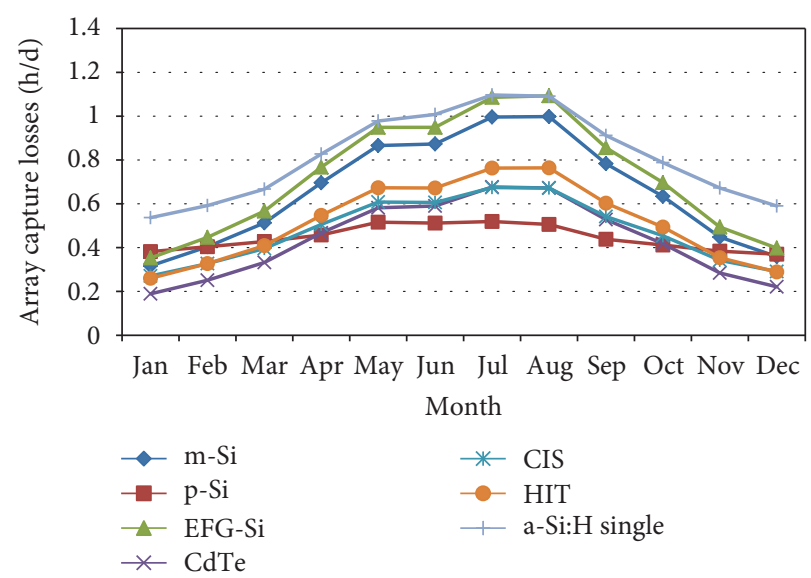

FIgURE 8: Monthly average array losses of seven PV module technologies.

Figure 7 shows the monthly average performance ratio of each PV module technology. The monthly average performance ratio of the CdTe technology was higher than that of the other technologies over the monitored period. However, the monthly average performance ratio of the a-Si:H singlePV technology was lower than that of the other technologies 


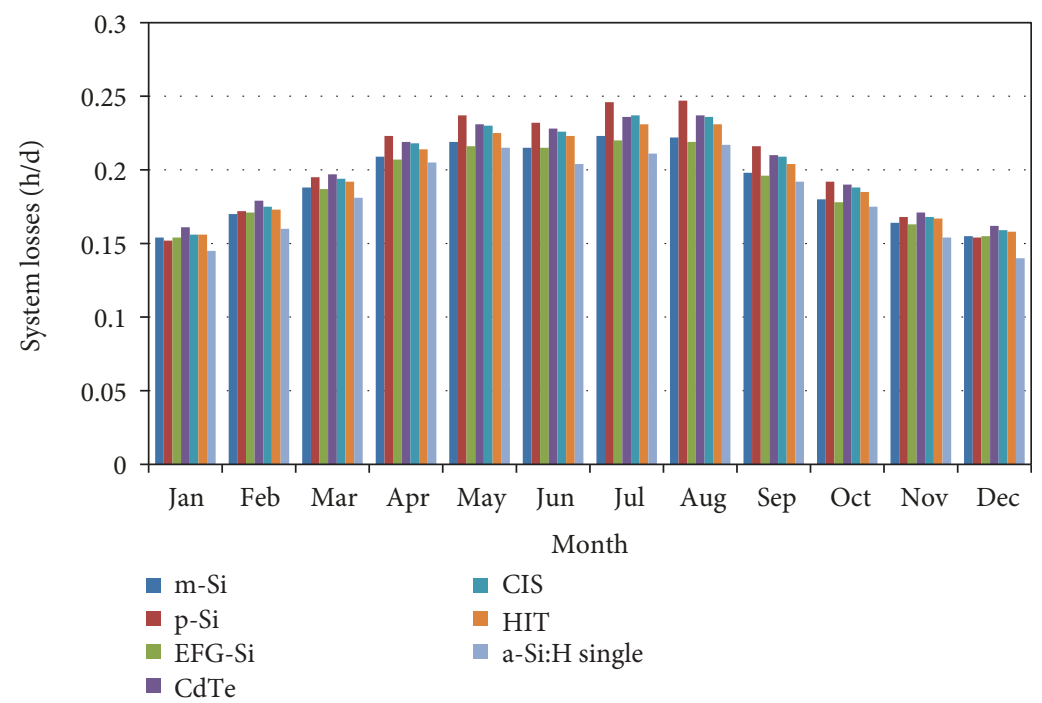

FIGURE 9: Monthly average system losses of seven PV module technologies.

over the twelve months. Note that the monthly average performance ratios of the $\mathrm{m}-\mathrm{Si}$, EFG-Si, CdTe, CIS, and HIT modules decreased from January to July but increased from July to December. It is clear that the PRs of the m-Si, EFG$\mathrm{Si}, \mathrm{CdTe}, \mathrm{CIS}$, and HIT were lowest in July. The variation in the monthly average performance ratio of the a-Si:H single-PV module is similar to the variation in the $\mathrm{m}-\mathrm{Si}$, EFG-Si, CdTe, CIS, and HIT modules. However, the monthly average performance ratio of the $\mathrm{p}$-Si increased from January to May, remained basically identical from May to July, and then decreased from August to December.

Figure 8 shows the monthly average array capture losses of each PV module technology. The monthly average array capture losses of the a-Si: $\mathrm{H}$ single-PV module were higher than those of the other technologies over the monitored period. Monthly array capture losses were relatively higher in summer (June to August) than in other seasons. This may have been due to high solar irradiation and air temperature.

Figure 9 shows the monthly average system losses of each PV module technology. The monthly average system losses of the p-Si module were higher than those of the other technologies over the monitored period. Monthly array system losses were also higher in summer and lower in winter (December to February). The maximum monthly array system loss for the $\mathrm{p}$-Si module due to the temperature effect was $0.247 \mathrm{~h} / \mathrm{d}$, which occurred in August, whereas the minimum value for the a-Si:H single-PV module was $0.14 \mathrm{~h} / \mathrm{d}$, which occurred in December.

\section{Conclusions}

The performance of $8 \mathrm{~kW}$ grid-connected solar PV power systems based on seven PV module technologies (m-Si, p$\mathrm{Si}, \mathrm{EFG}-\mathrm{Si}, \mathrm{CdTe}$, CIS, HIT, and a-Si:H single-PV) installed in Nanjing, China, has been investigated.

The yearly average energy output of the seven PV systems was $8831.1 \mathrm{kWh}, 9556 \mathrm{kWh}, 8584.4 \mathrm{kWh}, 9570 \mathrm{kWh}$,
$9411.2 \mathrm{kWh}, 9606 \mathrm{kWh}$, and $8424.1 \mathrm{kWh}$ for $\mathrm{m}-\mathrm{Si}, \mathrm{p}-\mathrm{Si}$, EFG-Si, CdTe, CIS, HIT, and a-Si:H single-PV, respectively. The maximum PV module and system efficiencies were $15.7 \%$ and $14.73 \%$, respectively, for the HIT PV module, whereas the minimum efficiencies were $3.15 \%$ and $2.95 \%$, respectively, for the a-Si:H single-PV module system. The array yield of these PV systems varied from a low value of $2.17 \mathrm{~h} / \mathrm{d}$ in January for the a-Si:H single-PV system to a high value of $4.18 \mathrm{~h} / \mathrm{d}$ in August for the $\mathrm{p}-\mathrm{Si} \mathrm{PV}$ system. The a-Si:H single-PV technology has the lowest monthly average final yield in January, with a value of $2.03 \mathrm{~h} / \mathrm{d}$, and a high value of $3.38 \mathrm{~h} / \mathrm{d}$ in August. The p-Si technology had the highest monthly average final yield in August, with a value of $3.93 \mathrm{~h} / \mathrm{d}$, and a low value of $2.17 \mathrm{~h} / \mathrm{d}$ in January.

The monthly average performance ratio of the CdTe technology was higher than those of the other technologies over the monitored period. However, the monthly average performance ratio of the a-Si:H single-PV technology was lower than those of the other technologies over the twelve months. The monthly average array capture losses of the a-Si:H single-PV module were higher than those of the other technologies over the monitored period. Monthly array capture losses were higher in summer (June to August) than in other seasons. The maximum monthly array system loss for the $\mathrm{p}$-Si module due to temperature was $0.247 \mathrm{~h} / \mathrm{d}$ and occurred in August, whereas the minimum value for the a-Si:H single-PV module was $0.14 \mathrm{~h} / \mathrm{d}$ and occurred in December.

\section{Data Availability}

Monthly meteorological data for Nanjing were available with the help of the METEONORM V7.0 software, which was used to generate hourly synthetic meteorological data. This study compares the performance of grid-connected solar PV power systems with seven PV technologies under hot summer and cold winter conditions using the PVsyst V5.74 tool. Simulations were carried out on the performance of 
different PV modules, taking into account the solar radiation and ambient temperature of Nanjing. I have finished writing this article aided by the METEONORM V7.0 and PVsyst V5.74 simulation software. Data is done through software. There is no experimental data.

\section{Conflicts of Interest}

The author declares that there is no conflict of interest.

\section{Acknowledgments}

The author would like to thank the editors and anonymous reviewers for their valuable comments and suggestions to improve the quality of the paper. The author is also grateful to the scientific research project of Nanjing Xiaozhuang University (No. 2017NXY41) and the talent introduction project of Nanjing Xiaozhuang University (No. 4177020).

\section{References}

[1] K. Kawajiri, T. G. Gutowski, and S. B. Gershwin, "Net $\mathrm{CO}_{2}$ emissions from global photovoltaic development," RSC Advances, vol. 4, no. 102, pp. 58652-58659, 2014.

[2] M. Asif, "Urban scale application of solar PV to improve sustainability in the building and the energy sectors of KSA," Sustainability, vol. 8, no. 11, pp. 1-11, 2016.

[3] E. R. Shouman, E. T. E. Shenawy, and N. M. Khattab, "Market financial analysis and cost performance for photovoltaic technology through international and national perspective with case study for Egypt," Renewable and Sustainable Energy Reviews, vol. 57, pp. 540-549, 2016.

[4] H. Wu, X. J. Wang, S. Shahid, and M. Ye, "Changing characteristics of the water consumption structure in Nanjing city, southern China," Water, vol. 8, no. 8, p. 8, 2016.

[5] "Nanjing maps," https://www.chinahighlights.com/nanjing/ map.htm.

[6] "Characteristics of Nanjing geographical climate," http://www. cma.gov.cn/2011xzt/2014zt/20140730/2014073002/20140730 0201/201408/t20140802_254423.html.

[7] "Nanjing climate \& weather," https://www.topchinatravel .com/nanjing/nanjing-climate-and-weather.htm.

[8] Z. H. Gu, Q. Sun, and R. Wennersten, "Impact of urban residences on energy consumption and carbon emissions: an investigation in Nanjing, China," Sustainable Cities and Society, vol. 7, pp. 52-61, 2013.

[9] E. Kymakis, S. Kalykakis, and T. M. Papazoglou, "Performance analysis of a grid connected photovoltaic park on the island of Crete," Energy Conversion and Management, vol. 50, no. 3, pp. 433-438, 2009.

[10] L. M. Ayompe, A. Duffy, S. J. McCormack, and M. Conlon, "Measured performance of a $1.72 \mathrm{~kW}$ rooftop grid connected photovoltaic system in Ireland," Energy Conversion and Management, vol. 52, no. 2, pp. 816-825, 2011.

[11] S. Wittkopf, S. Valliappan, L. Y. Liu, K. S. Ang, and S. C. J. Cheng, "Analytical performance monitoring of a $142.5 \mathrm{~kW}_{\mathrm{p}}$ grid-connected rooftop BIPV system in Singapore," Renewable Energy, vol. 47, no. 6, pp. 9-20, 2012.

[12] A. M. Al-Sabounchi, S. A. Yalyali, and H. A. Al-Thani, "Design and performance evaluation of a photovoltaic grid-connected system in hot weather conditions," Renewable Energy, vol. 53, no. 9, pp. 71-78, 2013.

[13] K. Padmavathi and S. A. Daniel, "Performance analysis of a $3 \mathrm{MW}_{\mathrm{p}}$ grid connected solar photovoltaic power plant in India," Energy for Sustainable Development, vol. 17, no. 6, pp. 615-625, 2013.

[14] M. Farhoodnea, A. Mohamed, T. Khatib, and W. Elmenreich, "Performance evaluation and characterization of a $3-\mathrm{kWp}$ grid-connected photovoltaic system based on tropical field experimental results: new results and comparative study," Renewable and Sustainable Energy Reviews, vol. 42, pp. 1047-1054, 2015.

[15] S. Sundaram and J. S. C. Babu, "Performance evaluation and validation of $5 \mathrm{MW}_{\mathrm{p}}$ grid connected solar photovoltaic plant in South India," Energy Conversion and Management, vol. 100, pp. 429-439, 2015.

[16] D. Okello, E. E. V. Dyk, and F. J. Vorster, "Analysis of measured and simulated performance data of a $3.2 \mathrm{~kW}_{\mathrm{p}}$ gridconnected PV system in Port Elizabeth, South Africa," Energy Conversion and Management, vol. 100, pp. 10-15, 2015.

[17] M. Mpholo, T. Nchaba, and M. Monese, "Yield and performance analysis of the first grid-connected solar farm at Moshoeshoe I International Airport, Lesotho," Renewable Energy, vol. 81, pp. 845-852, 2015.

[18] C. E. B. E. Sidi, M. L. Ndiaye, M. E. Bah, A. Mbodji, A. Ndiaye, and P. A. Ndiaye, "Performance analysis of the first large-scale $\left(15 \mathrm{MW}_{\mathrm{p}}\right)$ grid-connected photovoltaic plant in Mauritania," Energy Conversion and Management, vol. 119, no. 1, pp. 411-421, 2016.

[19] R. Dabou, F. Bouchafaa, A. H. Arab et al., "Monitoring and performance analysis of grid connected photovoltaic under different climatic conditions in south Algeria," Energy Conversion and Management, vol. 130, pp. 200-206, 2016.

[20] A. Allouhi, R. Saadani, T. Kousksou, R. Saidur, A. Jamil, and M. Rahmoune, "Grid-connected PV systems installed on institutional buildings: technology comparison, energy analysis and economic performance," Energy and Buildings, vol. 130, no. 15, pp. 188-201, 2016.

[21] H. Maammeur, A. Hamidat, L. Loukarfi, M. Missoum, K. Abdeladim, and T. Nacer, "Performance investigation of grid-connected PV systems for family farms: case study of north-west of Algeria," Renewable and Sustainable Energy Reviews, vol. 78, pp. 1208-1220, 2017.

[22] L. C. D. Lima, L. D. A. Ferreira, and F. H. B. D. L. Morai, "Performance analysis of a grid connected photovoltaic system in northeastern Brazil," Energy for Sustainable Development, vol. 37, pp. 79-85, 2017.

[23] H. M. Bahaidarah, B. Tanweer, P. Gandhidasan, N. Ibrahim, and S. Rehman, "Experimental and numerical study on non-concentrating and symmetric unglazed compound parabolic photovoltaic concentration systems," Applied Energy, vol. 136, pp. 527-536, 2014.

[24] H. M. Bahaidarah, P. Gandhidasan, A. A. B. Baloch, B. Tanweer, and M. Mahmood, "A comparative study on the effect of glazing and cooling for compound parabolic concentrator PV systems-experimental and analytical investigations," Energy Conversion and Management, vol. 129, pp. 227-239, 2016.

[25] A. Raghoebarsing and A. Kalpoe, "Performance and economic analysis of a $27 \mathrm{~kW}$ grid-connected photovoltaic system in Suriname," IET Renewable Power Generation, vol. 11, no. 12, pp. 1545-1554, 2017. 
[26] “PVSYST," http://www.pvsyst.com/.

[27] A. M. Humada, M. Hojabri, H. M. Hamada, F. B. Samsuri, and M. N. Ahmed, "Performance evaluation of two PV technologies (c-Si and CIS) for building integrated photovoltaic based on tropical climate condition: a case study in Malaysia," Energy and Buildings, vol. 119, pp. 233-241, 2016.

[28] H. A. Kazem, T. Khatib, K. Sopian, and W. Elmenreich, "Performance and feasibility assessment of a $1.4 \mathrm{~kW}$ roof top grid-connected photovoltaic power system under desertic weather conditions," Energy and Buildings, vol. 82, pp. 123129, 2014.

[29] B. Tripathi, P. Yadav, S. Rathod, and M. Kumar, "Performance analysis and comparison of two silicon material based photovoltaic technologies under actual climatic conditions in Western India," Energy Conversion and Management, vol. 80, pp. 97-102, 2014.

[30] "Meteonorm software," http://www.meteonorm.com/.

[31] V. Sharma, A. Kumar, O. S. Sastry, and S. S. Chandel, "Performance assessment of different solar photovoltaic technologies under similar outdoor conditions," Energy, vol. 58, no. 9, pp. 511-518, 2013.

[32] A. Balaska, A. Tahri, F. Tahri, and A. B. Stambouli, "Performance assessment of five different photovoltaic module technologies under outdoor conditions in Algeria," Renewable Energy, vol. 107, pp. 53-60, 2017.

[33] I. Jamil, J. Q. Zhao, L. Zhang, R. Jamil, and S. F. Rafique, "Evaluation of energy production and energy yield assessment based on feasibility, design, and execution of $3 \times 50 \mathrm{MW}$ grid-connected solar PV pilot project in Nooriabad," International Journal of Photoenergy, vol. 2017, Article ID 6429581, 18 pages, 2017.

[34] D. A. Quansah, M. S. Adaramola, G. K. Appiah, and I. A. Edwin, "Performance analysis of different grid-connected solar photovoltaic (PV) system technologies with combined capacity of $20 \mathrm{~kW}$ located in humid tropical climate," International Journal of Hydrogen Energy, vol. 42, no. 7, pp. 46264635, 2017. 

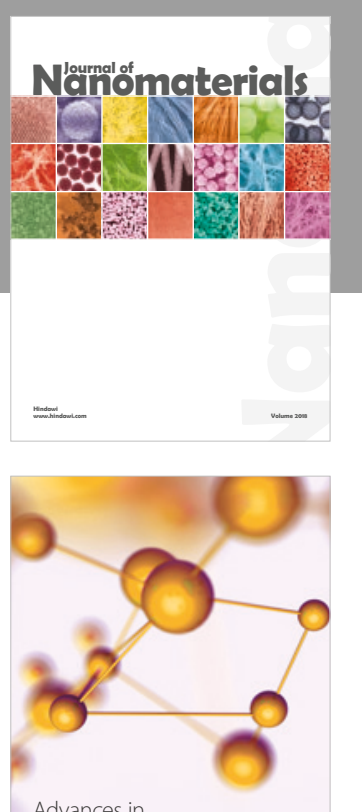

Physical Chemistry
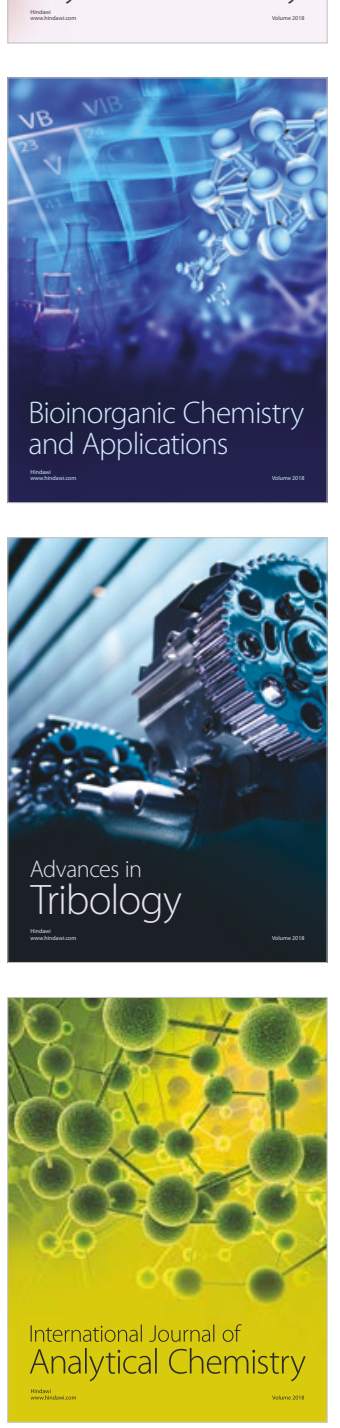

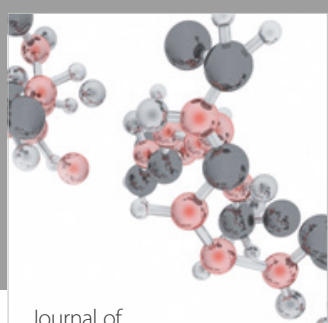

Analytical Methods

in Chemistry

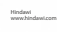

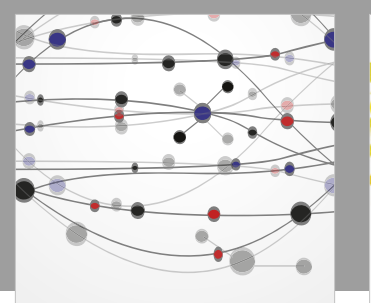

The Scientific World Journal

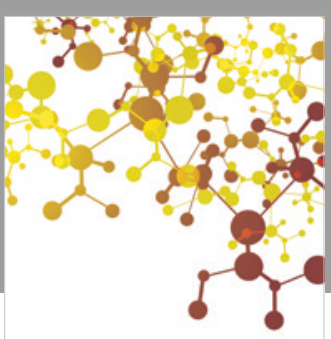

Journal of

Applied Chemistry
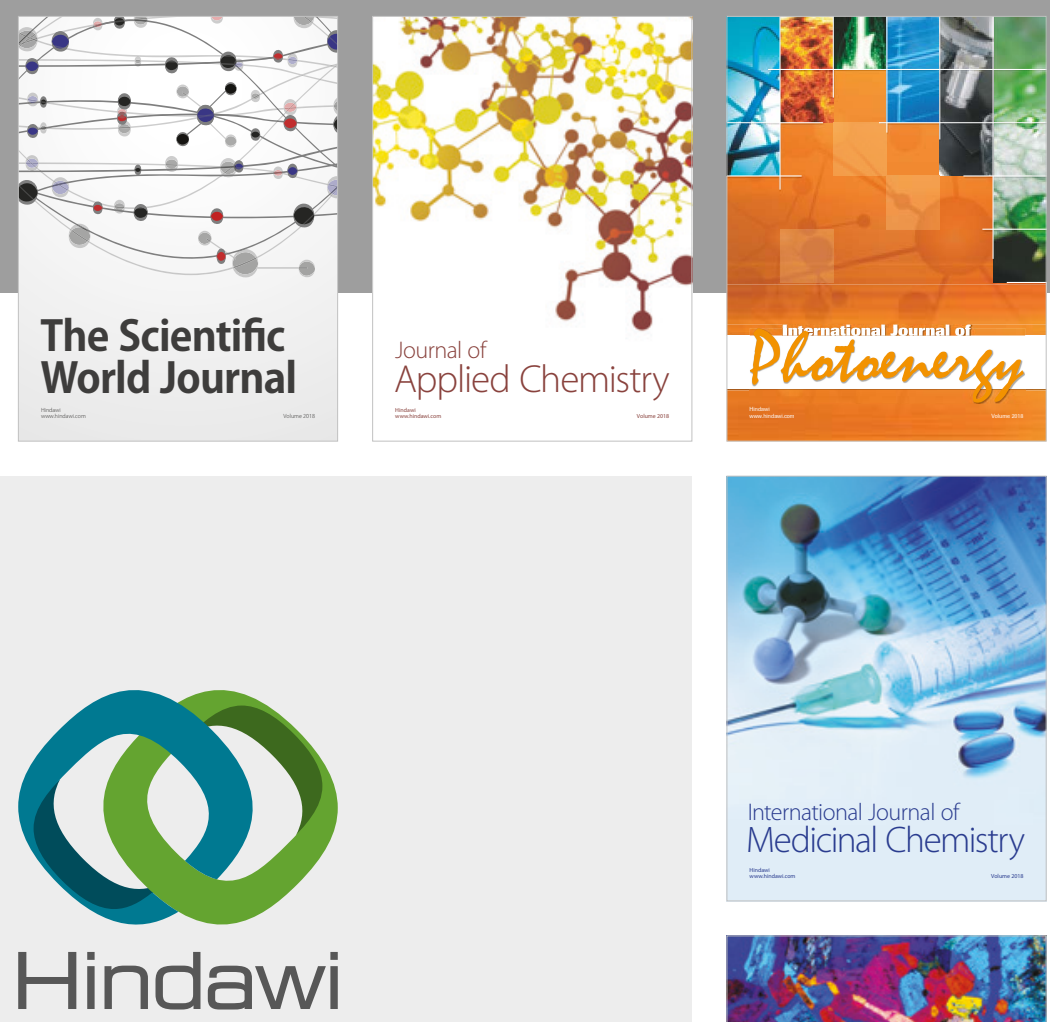

Submit your manuscripts at

www.hindawi.com
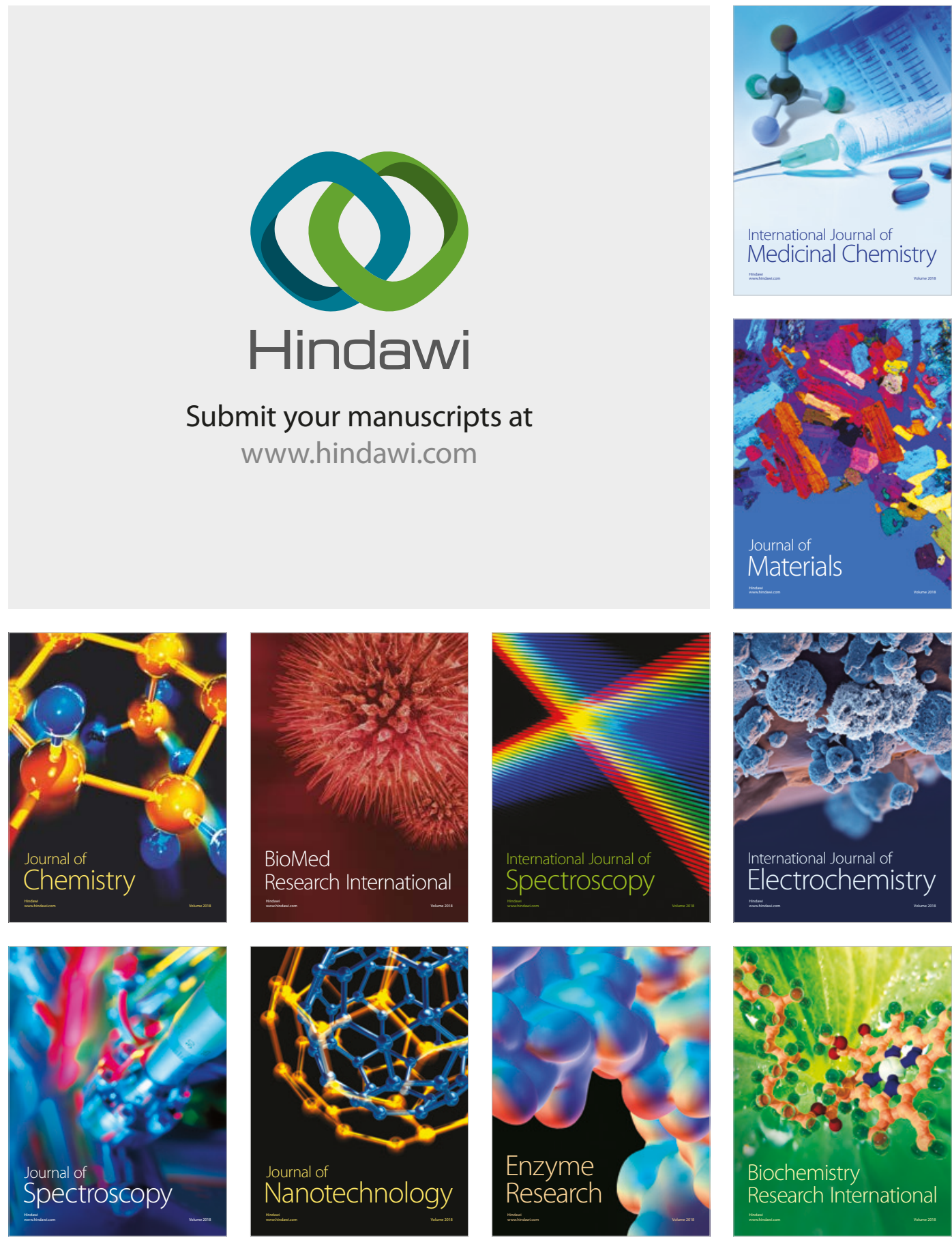
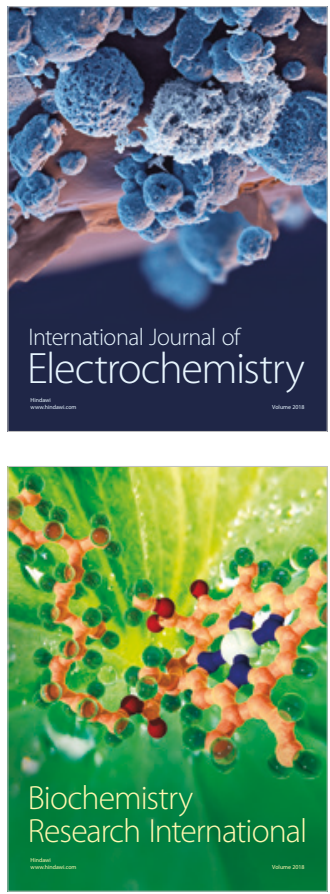